\title{
Growth and nutritional status of institutionalised children under five years in Colombo district, Sri Lanka
}

\author{
*Nimesha Chamidani Gamhewage ${ }^{1}$, Guwani Liyanage ${ }^{2}$, Ruwanthi Perera ${ }^{2}$ \\ Sri Lanka Journal of Child Health, 2017; 46(3): 230-233
}

\begin{abstract}
Introduction: Institutional care is the commonest solution for children deprived of parental care in Sri Lanka. They have multiple risk factors which can contribute to a worse outcome with regard to growth and development. Data regarding growth of Sri Lankan institutionalised children are lacking.
\end{abstract}

Objective: To assess growth and nutritional status of institutionalised children less than five years of age in the Colombo district.

Method: It is a descriptive cross sectional study conducted in 8 randomly selected voluntary foster care institutions in the Colombo District housing children less than five years old. Children with an uncertain date of birth, chronic illnesses and genetic or congenital defects were excluded from the study. Data on growth were compared with information on malnutrition of children below 5 years in Sri Lanka.

Results: One hundred and eighty children were enrolled in the study. Among girls, 21\% had moderate stunting and $13 \%$ severe stunting. In boys, $30 \%$ were moderately stunted and $8 \%$ severely stunted. In girls, prevalence of moderate and severe underweight was $25 \%$ and $18 \%$ respectively. In boys, $26 \%$ had moderate underweight and $17 \%$ had severe underweight. Whilst $20 \%$ of girls and $14 \%$ of boys were moderately wasted, $7 \%$ of girls and $8 \%$ of boys were severely wasted. Prevalence of stunting, underweight and wasting was significantly higher in the study cohort. $(\mathrm{p}<0.001$ for all three categories of malnutrition).

${ }^{1}$ Lady Ridgeway Hospital for Children, Colombo, Sri Lanka, ${ }^{2}$ Faculty of Medical Sciences, University of Sri Jayawardenepura, Sri Lanka

*Correspondence:nimeshagamhewage@gmail.com

(Received on 18 October 2016: Accepted after revision on 05 December 2016)

The authors declare that there are no conflicts of interest

Personal funding was used for the project.

Open Access Article published under the Creative

Commons Attribution CC-BY (CC)
Conclusion: Children less than five years of age in foster care institutions in Colombo district have significant growth impairment.

DOI: http://dx.doi.org/10.4038/sljch.v46i3.8323

(Key words: Institutionalised children, growth, Colombo District)

\section{Introduction}

Institutional care is the commonest solution for children deprived of parental care in Sri Lanka. They have multiple risk factors which can contribute to a worse outcome with regard to growth and development. Department of Probation and Child Care Services (DPCCS) statistics in 2010 show that there are 374 child care institutions in Sri Lanka, including state receiving homes with approximately 15,874 resident children ${ }^{1}$. In 2013, National Child Protection Authority of Sri Lanka published guidelines and standards for childcare institutions in Sri Lanka to ensure optimal development of these children in physical, mental, moral, religious, social, and cultural spheres and to protect them from exploitation and discrimination ${ }^{2}$. Jayasekera CR investigated the nutritional level of institutionalised children less than 5 years in three state receiving homes in Sri Lanka in 2004 and demonstrated that they have poor nutrition when compared to the national prevalence of undernutrition ${ }^{3}$. However, they had not included children from voluntary foster care institutions that cater to the majority of institutionalised children in Sri Lanka. Most of these foster care institutions are run by voluntary organizations funded by citizens and nongovernmental organizations and are termed "voluntary children's homes".

The first five years of a child's life are fundamentally important. Early experience at this stage has a direct impact on how children develop learning skills, social skills and emotional abilities. Therefore, providing optimal care for these children in their early years is very important. Institutionalised children could be deprived of optimal care during these important early years of life. In Sri Lanka, there are many institutions providing care for children less than 5 years. However, information of nutrition and development of these children are lacking. Dearth of information on these aspects prompted us to embark on this study. 


\section{Objective}

To assess growth and nutritional status of institutionalised children less than five years of age in Colombo district.

\section{Method}

It is a descriptive cross sectional study. We included children from 8 randomly selected voluntary foster care institutions in Colombo district housing children less than five years. Sample calculation was performed taking the prevalence of children having wasting in the Colombo metropolitan area ${ }^{4}$. Permission was obtained from the DPCCS and the procedure of data collection was detailed to the administrative staff of each centre. Confidentiality of all records was maintained. Ethical clearance was obtained from the Ethical Review Committee of the Faculty of Medicine, University of Colombo. Data collected from children with an uncertain date of birth (in whom the date of birth could not be obtained either from Child Health Development Record or documents available at the institution), chronic illnesses and genetic or congenital defects were excluded from the study.

Anthropometry (weight, height or length) was obtained by standard techniques. They were weighed on a spring balance with $100 \mathrm{~g}$ accuracy. Recumbent length was obtained for those less than 24 months of age, using an infantometer and height was measured in older children with a stadiometer. All measurements were done by trained investigators. Random cross checking was done to reduce the variability between investigators. World Health Organisation growth standards were used to describe stunting (below -2 standard deviations (SD) from median height for age of reference population), wasting (below -2SD from median weight for height of reference population) and underweight (below -2 SD from median weight for age of reference population $)^{5}$. For each indicator of growth between -2 to $-3 \mathrm{SD}$ was considered moderate, and below -3 SD was considered severe. Data on nutrition were compared with information on malnutrition of children below 5 years in Sri Lanka. National and district level data on protein energy malnutrition is available from surveys conducted in Sri Lanka ${ }^{4,6}$.

Data was analysed using SPSS version 20. Descriptive statistics were used for categorical data. Chi square test was applied for comparisons and $\mathrm{p}$ value of $<0.05$ was taken as significant.

\section{Results}

A total of 180 children were included in the study. Table 1 describes the characteristics of the study population.

Table 1

Characteristics of the study population $(n=180)$

\begin{tabular}{|l|l|}
\hline \multicolumn{1}{|c|}{ Characteristic } & Number (\%) \\
\hline Age & $61(33.9)$ \\
$0-24$ months & $75(41.6)$ \\
$25-48$ months & $44(24.5)$ \\
$49-60$ months & $103(57.3)$ \\
\hline Sex & $77(42.7)$ \\
Female & \\
Male & $115(63.9)$ \\
\hline Age at institutionalisation & $34(18.9)$ \\
$0-12$ months & $31(17.2)$ \\
13-36 months & $137(76.1)$ \\
$37-60$ months & $38(21.1)$ \\
\hline Birth weight & $05(02.8)$ \\
Normal & $71(39.4)$ \\
Low (<2.5kg) & $109(60.6)$ \\
Not available & \\
\hline Duration of institutionalisation & \\
0-12 months & \\
More than 12 months &
\end{tabular}

Sixty five $(36.1 \%)$ of the study population were observed to be having stunting while 78 (43.3\%) children were underweight. Prevalence of wasting in the study cohort was $46(25.5 \%)$ children. Growth parameters of the study population are summarized in table 2.

Table 2: Prevalence of stunting, underweight and wasting of the study population

\begin{tabular}{|l|c|c|c|c|c|c|}
\hline \multirow{2}{*}{} & \multicolumn{2}{|c|}{ Stunting } & \multicolumn{2}{c|}{ Underweight } & \multicolumn{2}{c|}{ Wasting } \\
\cline { 2 - 7 } & $\begin{array}{c}\text { Moderate } \\
\text { No. (\%) }\end{array}$ & $\begin{array}{c}\text { Severe } \\
\text { No. (\%) }\end{array}$ & $\begin{array}{c}\text { Moderate } \\
\text { No. (\%) }\end{array}$ & $\begin{array}{c}\text { Severe } \\
\text { No. (\%) }\end{array}$ & $\begin{array}{c}\text { Moderate } \\
\text { No. (\%) }\end{array}$ & $\begin{array}{c}\text { Severe } \\
\text { No. (\%) }\end{array}$ \\
\hline Girls & $22(21)$ & $14(13)$ & $26(25)$ & $19(18)$ & $21(20)$ & $07(07)$ \\
\hline Boys & $23(30)$ & $06(08)$ & $20(26)$ & $13(17)$ & $11(14)$ & $06(08)$ \\
\hline
\end{tabular}

Data on growth of study population were compared with information on malnutrition of children below 5 years in the Colombo district. Data on growth of the Colombo district children were obtained from Sri Lanka Demographic and Health Survey 2006$07^{6}$. Significantly higher prevalences of stunting, underweight and wasting were observed in the study cohort when compared to their mothered peers in household environments from the Colombo district. $(\mathrm{p}<0.001$ for stunting, wasting and underweight.) The comparison of prevalence of malnutrition between national statistics and the study population (institutionalised children) is summarized in Table 3. 
Growth and nutritional status of institutionalised ..... Sri Lanka Journal of Child Health, 2017; 46(3): 230-233

Table 3: Comparison of prevalence of malnutrition of institutionalised children to national prevalence

\begin{tabular}{|c|c|c|c|c|c|c|}
\hline \multirow[t]{2}{*}{$\begin{array}{l}\text { Category of } \\
\text { malnutrition }\end{array}$} & \multicolumn{2}{|c|}{ National level } & \multicolumn{2}{|c|}{$\begin{array}{l}\text { Colombo metro and } \\
\text { other urban }\end{array}$} & \multirow{2}{*}{$\begin{array}{l}\text { Prevalence of } \\
\text { malnutrition in } \\
\text { study cohort }\end{array}$} & \multirow[t]{2}{*}{$\begin{array}{c}\mathbf{p} \\
\text { value }\end{array}$} \\
\hline & NFSA 2009 & DHS 2006-07 & NFSA 2009 & DHS 2006-7 & & \\
\hline Stunting (\%) & 19.2 & 17.3 & 14.3 & 13.8 & 36.1 & $<0.001$ \\
\hline Under weight $(\%)$ & 21.6 & 21.1 & 17.7 & 16.5 & 43.3 & $<0.001$ \\
\hline Wasting (\%) & 11.7 & 14.7 & 11.0 & 14.7 & 25.5 & $<0.001$ \\
\hline
\end{tabular}

\section{Discussion}

Our study shows that the prevalence of malnutrition is higher among institutionalised children when compared with national prevalence. The only study in Sri Lanka that evaluated growth in institutionalised children was done by Jayasekara $\mathrm{CR}$ and it concluded that children in institutions had low growth compared to the children who are not institutionalized ${ }^{3}$. As they had recruited children residing in 3 randomly selected State Receiving Homes, which are transit centres for these children, it does not reflect the long term effect on the growth of institutionalized children. Furthermore, this study had been conducted more than a decade ago and had used $1978 \mathrm{NCHS} / \mathrm{WHO}$ growth reference for assessment of growth ${ }^{3}$.

In general, causes of malnutrition are multifactorial. Poverty leads to food insecurity in households. However, poverty per se cannot explain the present rate of malnutrition among children less than 5 years of age in Sri Lanka. It is likely that many other reasons ranging from acute and chronic diseases, lack of knowledge on utilization of health services, poor maternal health, inadequate understanding and cultural influence on selection of nutritious food may be playing a substantial role in causation ${ }^{7}$. There may be other factors that contribute to growth problems in institutionalised children.

Facilities available in homes for care of children could be responsible for optimal growth. An island wide survey conducted by UNICEF in 2007 has highlighted that two thirds of institutions providing home for children are not equipped with essential facilities $^{8}$. Water and food, medical facilities, individual care, contact with families where possible and leisure activities are yet to be improved. It concluded that Sri Lanka is far from reaching the ability of the children to grow up in a family like environment, which is the best for optimal growth and development ${ }^{8}$.

Further, low birth weight can also contribute to poor growth during childhood. Statistics of the Family Health bureau, 2013 reveals that low birth weight is $13.3 \%$ in Sri Lanka ${ }^{9}$. In our study 38 (21\%) children were born with a low birth weight which is higher than the prevalence at national level. Antenatal and perinatal risk factors such as unwanted pregnancy, poor antenatal care, use of illicit drugs and teenage pregnancies could be possible reasons for higher rate of low birth weight in our cohort.

There is adequate evidence from the rest of the world that institutionalisation per se has a negative impact on child's life, in spite of adequate facilities. Social and behavioral abnormalities, poor growth, reduced intelligence quotient, development delay and emotional reactivity are among them ${ }^{10}$.

All of us who are involved in child welfare should take every effort to provide for the physical, intellectual and emotional needs of these children. Regular growth and development monitoring of institutionalised children is very important to employ early and appropriate interventions. We are fortunate to have a strong primary care network where the midwife plays a major role, which could be utilized to strengthen the care of these children. The Child Health Development Record is an important tool in monitoring. It acts as a personal file for each child. Training programmes to strengthen the knowledge of the staff in these institutions on nutrition and development will invariably improve care. Establishment of skills development centres within the institution is useful to enhance the overall development of children. A system should be put in place to identify institutions with lack of essential facilities. Moreover, welfare of these children probably needs changing the perspective towards strengthening the link between these children and their families which will enhance emotional, social and behavioural development. This will enable them to develop skills to function and adapt better in the society when they grow up.

\section{Conclusion}

Children less than five years of age in foster care institutions in Colombo district have significant growth impairment.

\section{References}

1. Department of Probation and Child Care Services. Statistics report 2010 Viewed on: http://www.probation.gov.lk/

2. National Child Protection Authority. Guidelines and Standards for Childcare Institutions. Available on:

http://www.childprotection.gov.lk/docume nts/guidelines 
3. Jayasekara CR. Nutritional status of children under five in three state foster care institutions in Sri Lanka. Ceylon Medical Journal 2006; 51(2): 63-5.

4. Sri Lanka Demographic and Health Survey 2006-07. Department of Census and Statistics Colombo, Sri Lanka. April 2009. http://www.statistics.gov.lk/social/DHS/Fi nalReport.pdf

5. World Health Organization. The WHO Child Growth Standards. Available on: http://www.who.int/childgrowth/standards len/

6. Nutrition and food security assessment in Sri Lanka. March 2010. Available on: http://documents.wfp.org/stellent/groups/p ublic/documents/ena/wfp245807.pdf

7. Jayatissa R, Wickramasinghe R, Bekele A. Child undernutrition in Sri Lanka: Causal analysis 2006. Available from: http://www.mri.gov.lk/
8. Roccella C. Out of Sight, Out of Mind, Report on Voluntary Residential Institutions for Children in Sri Lanka: Statistical Analysis. UNICEF, 2007. Available from:

www.unicef.org/srilanka/outofsignt.pdf

9. Family Health Bureau, Ministry of Health and Indigenous Medicine of Sri Lanka. Statistics. Available from: http://www.fhb.health.gov.lk

10. Joint Council Summary Report on the Bucharest Early Intervention Study, 2009. Available from: https://betheanswerforchildren.files.wordp ress.com/2011/03/summary-report-on-thebucharest-early-intervention-study-v-f.pdf 